\title{
IDENTIFIKASI TIMBULAN DAN EMISI GAS RUMAH KACA SAMPAH PASAR DI KOTA SURABAYA
}

\author{
Lina Indawati \\ Program Studi Teknik Sipil, Universitas Sebelas Maret. \\ Jl. Ir. Sutami 36 A, Kentingan Surakarta 57126. Telp. (0271) 634524, Fax 662118. \\ Email: linainda@staff.uns.ac.id.
}

\begin{abstract}
Market waste became a serious problem in Surabaya because it was the second largest waste after residential waste and a contributor to greenhouse gas emissions. Waste management through a new paradigm was carried out by reducing, limiting and reusing waste generations so as to reduce greenhouse gas emissions. The purpose of this study was to identify emissions generated from market waste. The release of greenhouse gas emissions were identified through the Life Cycle Assessment (LCA) approach. The approach with LCA was carried out with a 3 scenario approach, namely scenario 1 waste was sent to the final disposal, scenario 2 only waste vegetables, food, plastic, paper and metal were recycled, scenario 3 only vegetable and food waste were recycled. The largest emission of $\mathrm{CH}_{4}$ and $\mathrm{CO}_{2}$ gas produced by scenario 1 was $4.9 \mathrm{Gg} /$ year, and $237.21 \mathrm{Gg} /$ year. Recycling paper, plastic, metal, glass, vegetables and food waste significantly reduced $\mathrm{CH}_{4}$ emissions from $4.9 \mathrm{Gg} /$ year to $1.5 \mathrm{Gg} /$ year and reduced $\mathrm{CO}_{2}$ emissions from $237.21 \mathrm{Gg} /$ year to $-48.17 \mathrm{Gg} /$ year. Recycling of vegetable and food waste in scenario 3 was considerably reduce $\mathrm{CH}_{4}$ emissions so that $\mathrm{CH}_{4}$ emissions became $2.3 \mathrm{Gg} /$ year and $\mathrm{CO}_{2}$ emissions to $-0.245 \mathrm{Gg} /$ year.
\end{abstract}

Keywords: Emisi, green house gas, LCA, market waste,

\begin{abstract}
Abstrak
Sampah Pasar menjadi masalah yang serius di Kota Surabaya karena salah satu penyumbang emisi gas rumah kaca dan merupakan sampah terbesar kedua setelah sampah rumah tangga. Pengelolaan sampah melalui paradigma baru dapat dilakukan melalui reduksi sampah, pembatasan timbulan sampah serta pemanfaatan kembali sampah sehingga dapat mengurangi emisi gas rumah kaca yang terlepas ke udara. Tujuan dari penelitian ini adalah mengidentifikasi emisi yang ditimbulkan dari sampah pasar. Pelepasan emisi gas rumah kaca dapat diidentifikasi melalui pendekatan Life Cycle Assessment (LCA). Pendekatan dengan LCA dilakukan dengan pendekatan 3 skenario yaitu skenario 1 sampah langsung dikirim ke TPA, skenario 2 hanya sampah sayuran, makanan, plastik, kertas dan logam di daur ulang, skenario 3 hanya sampah sayuran dan makanan yang didaur ulang. Emisi terbesar gas $\mathrm{CH}_{4}$ dan $\mathrm{CO}_{2}$ dihasilkan oleh skenario 1 sebesar 4,9 Gg/tahun, dan 237, $21 \mathrm{Gg} / \operatorname{tahun}$. Adanya daur ulang sampah kertas, plastik, logam, kaca, sayuran dan makanan akan mengurangi emisi $\mathrm{CH}_{4}$ yang signifikan dari 4,9 Gg/tahun menjadi 1,5 Gg/tahun dan mengurangi emisi $\mathrm{CO}_{2}$ dari 237,21 Gg/tahun menjadi -48,17 Gg/tahun. Daur ulang sampah sayuran dan makanan pada skenario 3 mampu mengurangi emisi $\mathrm{CH}_{4}$ yang cukup besar sehingga emisi $\mathrm{CH}_{4}$ menjadi 2,3 Gg/tahun dan emisi $\mathrm{CO}_{2}$ menjadi $-0,245 \mathrm{Gg} /$ tahun.
\end{abstract}

Kata Kunci : Emisi, gas rumah kaca, $L C A$, sampah pasar

\section{PENDAHULUAN}

Sampah masih menjadi masalah yang serius di Kota Surabaya. Hal ini disebabkan Kota Surabaya termasuk lima kota besar yang memiliki timbulan sampah terbesar (Andina, 2019). Timbulan sampah Kota surabaya mencapai 2.913,18 ton/hari pada tahun 2017 dan pada tahun 2018 mengalami penurunan menjadi 2.164, 4 ton/ hari (Andina, 2019). Prosentase timbulan sampah rata-rata di Indonesia berdasarkan sumbernya yang cukup besar antara lain berasal dari rumah tangga (32,5\%), pasar (20,9\%), sarana publik (6,4\%), kawasan (8,5\%), perkantoran (5,4\%), pusat perniagaan $(9,3 \%)$ dan lainnya $(17 \%)$ (KLHK, 2020). Pada tahun 2020 timbulan sampah pasar memiliki prosentase sebesar 20,9\% yang merupakan prosentase timbulan sampah tertinggi kedua setelah sampah rumah tangga. Selain itu sampah merupakan penyumbang emisi Gas Rumah Kaca (GRK) terbesar kedua di Kota Surabaya (Dinas Lingkungan Hidup Kota Surabaya, 2014). Salah satu emisi GRK yang menjadi penyebab pemanasan global adalah emisi gas metana $\left(\mathrm{CH}_{4}\right)$ dan gas karbondioksida $\left(\mathrm{CO}_{2}\right)$. Sampah pasar sebagian besar memiliki komposisi sampah sayuran dan makanan sangat berpotensi menyumbang emisi $\mathrm{CH}_{4}$ dan $\mathrm{CO}_{2}$. Salah satu cara untuk mengatasi permasalahan sampah pasar dan emisi yang ditimbulkannya adalah dengan meminimalisasi timbulan sampah pasar, melakukan identifikasi timbulan dan emisi GRK yang ditimbulkan guna menentukan strategi pengelolaan dan pengolahan sampah pasar yang tepat.

Berdasarkan Undang-Undang No. 18 Tahun 2008, pengelolaan sampah melalui paradigma baru dapat dilakukan melalui reduksi sampah, pembatasan timbulan sampah serta pemanfaatan kembali sampah. Paradigma baru ini 
menjadi sangat penting dikarenakan timbulan sampah dalam jumlah yang besar dapat melepas emisi gas rumah kaca seperti $\mathrm{CH}_{4}$. Pelepasan emisi gas rumah kaca dapat diidentifikasi sedini mungkin melalui pendekatan Life Cycle Assessment (LCA). Melaui pendekatan LCA dampak suatu kegiatan yang mengarah pada pemanasan global dapat diperkirakan sedini mungkin guna menacari solusi terhapap pencegahan terjadinya pemanasan global melalui perbaikan lingkungan.

Pengelolaan sampah di Surabaya saat ini selain dilakukan penimbunan pada Tempat Pemrosesan Akhir (TPA) juga mulai menerapkan paradigma baru melalui pengolahan/pengurangan sampah dengan pengomposan. Pengomposan yang dilakukan di Surabaya menyerap sebagian besar sampah organik yang telah dilakukan pemilahan atau komposisi sampah organiknya cukup besar dan sangat sedikit tercampur sampah non-organik seperti plastik, kaca maupun logam. Sebagian besar jenis sampah berdasarkan sumbernya yang berpotensi dikomposkan berasal dari sampah pasar. Tidak hanya pembuangan dan penimbunan sampah pada TPA, tetapi pada proses pengomposan juga menghasilakan emisi GRK seperti $\mathrm{CH}_{4}$ dan $\mathrm{CO}_{2}$. Selain itu sampah pasar merupakan sampah dengan prosentasi tertinggi kedua sebesar $20,9 \%$ dari total timbulan sampah setelah sampah dari rumah tangga yang sebesar 32,5\%. Timbulan sampah yang cukup besar dan memiliki komposisi sampah sayuran dan makan sangat berpotensi menyumbang emisi gas $\mathrm{CH}_{4}$ dan $\mathrm{CO}_{2}$ ketika dikomposkan maupun dibuang ke TPA. Akan tetapi pada penelitian sebelumnya sebagian besar identifikasi emisi sampah di Surabaya hanya dilakukan pada sektor rumah tangga. Sehingga berdasarkan permasalahan ini perlu adanya identifikasi terkait timbulan dan perkiraan emisi yang ditimbulkan dari sampah pasar mengingat pasar merupakan sumber sampah terbesar kedua setelah sumber sampah yang berasal dari rumah tangga.

\section{METODE}

\section{Perhitungan Timbulan Sampah}

Perhitungan timbulan sampah pasar Kota Surabaya didapatkan dari perkalian data sekunder prosentase sampah pasar dengan total timbulan sampah Kota Surabaya. Sedangkan untuk timbulan komposisi sampah pasar didapatkan dari perkalian timbulan sampah pasar dengan prosentasi komposisi sampah pasar

\section{Perhitungan Emisi Sampah}

Perkiraan emisi $\mathrm{CH}_{4}$ dan $\mathrm{CO}_{2}$ diidentifikasi melalui pendekatan LCA. Pendekatan LCA dilakukan dengan pendekatan 3 skenario yang mewakili kondisi di lapangan. skenario 1 sampah langsung dikirim ke TPA, skenario 2 hanya sampah sayuran, makanan, plastik, kertas dan logam di daur ulang, skenario 3 hanya sampah sayuran dan makanan yang didaur ulang (Gambar 1). Skenario 1 mewakili pasar yang belum melakukan upaya reduksi sampah pasar atau belum memiliki rumah kompos sehingga seluruh sampah pasar dikirim ke TPA. Skenario 2 mewakili pasar yang sudah melakukan reduksi/daur ulang sampah sayuran, makanan, plastik, kertas dan logam. Skenario 3 mewakili kondisi pasar yang hanya mampu mereduksi/mendaur ulang sampah sayuran dan makanan.

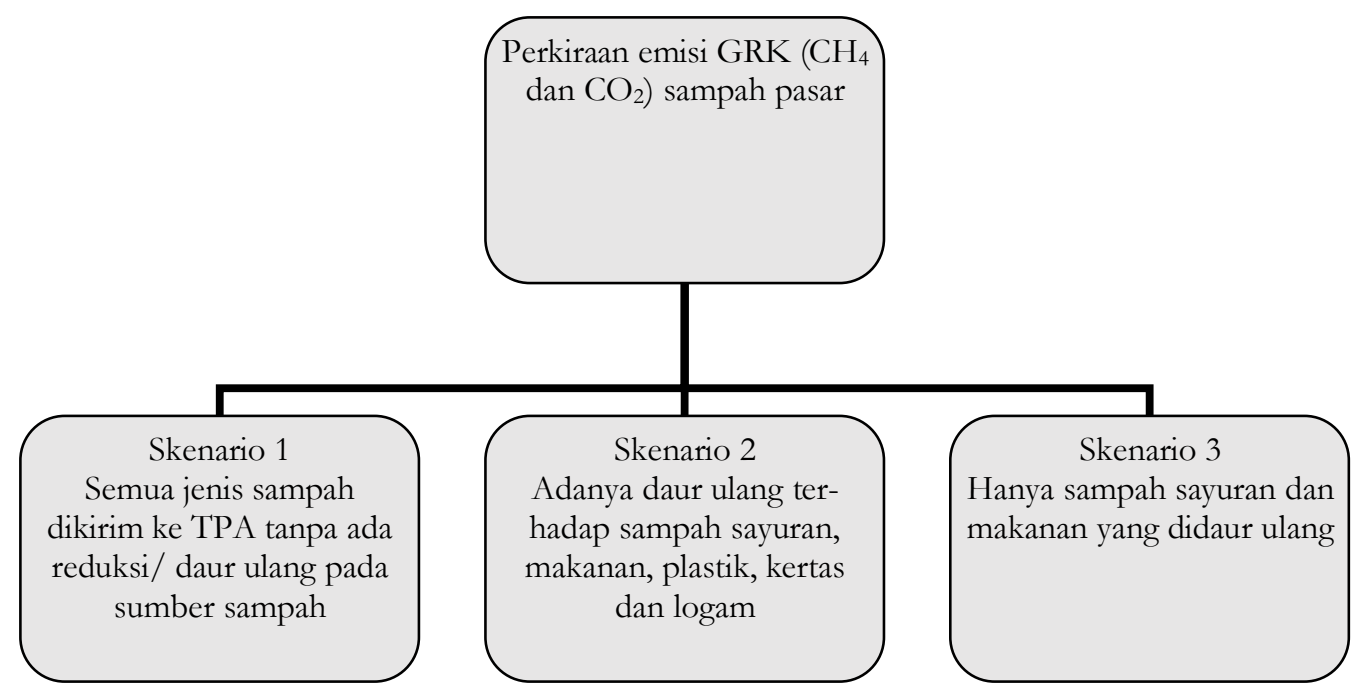

Gambar 1. Perkiraan emisi GRK rumah kompos 


\section{Emisi dari sampah yang dibuang ke TPA (tanpa dilakukan upaya reduksi)}

Data yang diolah merupakan data sekunder timbulan sampah pasar Kota Surabaya dan data sekunder prosentase timbulan sampah pasar Kota Surabaya. Perkiraan ini didekati dengan prinsip Life Cycle Assessment. Perhitungan emisi karbondioksida $\left(\mathrm{CO}_{2}\right)$ dan metana $\left(\mathrm{CH}_{4}\right)$ dari sampah yang dibuang ke TPA (tanpa dilakukan upaya reduksi) menggunakan persamaan [1] berdasarkan IPCC, (2006) dalam Hapsari dan Wilujeng, (2011).

Emisi Metana $=\left(\right.$ MSW $_{\mathrm{T}} \times \mathrm{MSW}_{\mathrm{F}} \mathrm{x}$ MCF $\mathrm{x}$ DOC $\mathrm{x}$ DOCF $\mathrm{x}$ F x 16/12- R $) \times(1-\mathrm{OX})$

Keterangan :

$\mathrm{MSW}_{\mathrm{T}}$

$\mathrm{MSW}_{\mathrm{F}}$

$=$ Timbulan sampah $(\mathrm{Gg} / \mathrm{yr})$

MCF $\quad$ Faktor koreksi metana. Nilai faktor adalah $0,4-1,0$ tergantung pada kemampuan masing-

$=$ Prosentase sampah yang masuk ke TPA dibandingkan jumlah sampah yang dihasilkan dari sumber. Nilai ini diperoleh dari data sekunder (\%) masing negara mengelola gas yang dihasilkan dari sampah di TPA.

DOC= Degradasi organik karbon (fraksi) $(\mathrm{Kg} \mathrm{C} / \mathrm{Kg}$ sampah). Dihitung dengan nilai DOC $\mathrm{x}$ massa komposisi sampah yang menghasilkan metana.

DOC $_{\mathrm{F}} \quad=$ Nilai DOC berdasarkan penelitian. Berdasarkan penelitian sebelumnya, suhu pada zona anaerobik adalah $35^{\circ} \mathrm{C}$, dan dimasukkan dalam rumus $0,014 \mathrm{~T}+0,28$ dan didapat nilai 0,77

$\mathrm{F} \quad=$ Fraksi dari $\mathrm{CH}_{4}$ di TPA $(0,5$ berdasarkan IPCC)

$\mathrm{R}=\mathrm{Recovery} \mathrm{CH}_{4}(\mathrm{Gg} / \mathrm{yr})$. Untuk kota yang belum memiliki sistem recovery gas, maka dianggap

OX $=$ Faktor oksidasi (0,1 berdasarkan IPCC). Faktor oksidasi yang dimaksud adalah besar $\mathrm{CH}_{4}$ yang teroksidasi oleh bakteri pengoksidasi pada permukaan tanah landfill.

\section{Emisi dari kegiatan reduksi sampah}

Data yang diolah merupakan data sekunder timbulan sampah pasar Kota Surabaya dan data sekunder prosen-tase timbulan sampah pasar Kota Surabaya. Perkiraan ini didekati dengan prinsip Life Cycle Assessment. Perhitungan emisi karbondioksida $\left(\mathrm{CO}_{2}\right)$ dan metana $\left(\mathrm{CH}_{4}\right)$ dari sampah yang didaur ulang menggunakan persamaan [2] sampai dengan persamaan [6] dan sebagian dibuang ke TPA (tanpa dilakukan upaya reduksi) menggunakan persamaan [7] sampai dengan persamaan [9] berdasarkan US-EPA, (2002) dalam Hapsari dan Wilujeng, (2011).

Emisi Metana $=\mathrm{MSK} \times \mathrm{EF} \mathrm{CH}_{4}$

Keterangan :

MSK = Massa sampah dikomposkan (ton)

$\mathrm{EF} \mathrm{CH}_{4} \quad=$ Faktor emisi $\mathrm{CH}_{4}(\mathrm{Kg} / \mathrm{Gg})$

Emisi Karbon (MTCE) $=$ MSK (ton) $\mathrm{x} \%$ komposisi sampah yang dikomposkan $\mathrm{x}$ faktor emisi karbon sampah

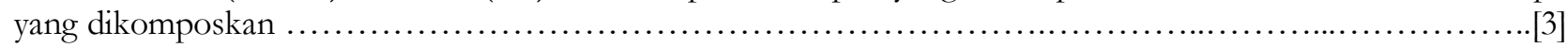

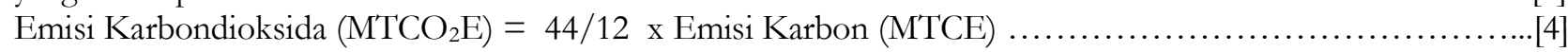

\section{Penggunaan ulang sampah}

Emisi Karbon (MTCE) = Berat sampah plastik yang digunakan ulang (ton) $\mathrm{x} \%$ komposisi sampah tereduksi $\mathrm{x}$

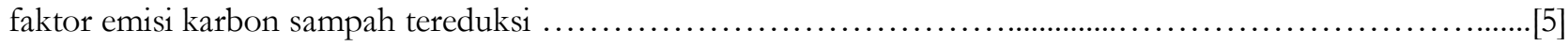

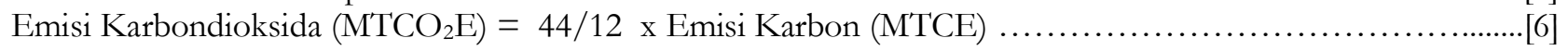

\section{Sampah yang tidak direduksi}

Emisi $\mathrm{CH}_{4}\left(\mathrm{MTCO}_{2} \mathrm{E} \mathrm{CH}_{4}\right)=$ Massa Sampah (ton) $\mathrm{x} \%$ komposisi sampah A $\mathrm{x}$ faktor emisi $\mathrm{CH}_{4}$ komponen

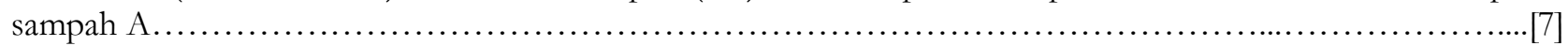

Emisi Karbon $($ MTCE) = Massa sampah (ton) $\mathrm{x} \%$ komposisi sampah A x faktor emisi karbon komponen

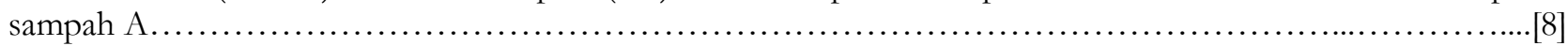

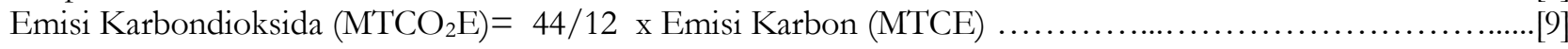

Keterangan:

MTCE = Mega Ton CE

$\mathrm{MTCO}_{2} \mathrm{E} \quad=$ Mega Ton $\mathrm{CO}_{2} \mathrm{E}$ 


\section{HASIL DAN PEMBAHASAN}

Timbulan Sampah Pasar

Perhitungan timbulan sampah didapatkan dari perhitungan data sekunder timbulan total sampah Kota Surabaya yang diaklikan dengan prosentase timbulan sampah pasar di Indonesia. Perhitungan ini menunjukkan bahwa timbulan sampah pasar pada tahun 2018 sebesar 432,88 ton/hari (Tabel 1). Di Indonesia, sektor pasar merupakan sektor penghasil timbulan sampah terbesar kedua setelah sektor rumah tangga.

Tabel 1. Timbulan sampah pasar

\begin{tabular}{rlll}
\hline Tahun & $\begin{array}{l}\text { Timbulan } \\
\text { Sampah } \\
\text { Kota Su- } \\
\text { rabaya } \\
\text { (ton/hari) }\end{array}$ & $\begin{array}{l}\text { Prosentase } \\
\text { Timbulan } \\
\text { Sampah(\%) }\end{array}$ & $\begin{array}{l}\text { Timbulan } \\
\text { Sampah } \\
\text { Pasar } \\
\text { (ton/hari) }\end{array}$ \\
\hline 2018 & $2.164,4$ & 20,9 & 452,1 \\
2017 & $2.913,18$ & 20,9 & 608,1 \\
\hline
\end{tabular}

Sumber: Hasil Perhitungan

Menurut Fathoni dan Soedjono, (2011) komposisi sampah pasar yang pasar yang paling dominan pada sampah pasar adalah sampah sayuran dan makan. Sampah sayuran dan makanan merupakan sampah yang berpotensi untuk dikomposkan yang mana pada proses degradasinya berpotensi menghasilkan gas $\mathrm{CH}_{4}$ dan $\mathrm{CO}_{2}$. Pada gambar 1 dapat dilihat prosentasi komposisi sampah pasar Kota Surabaya.

Perhitungan timbulan komposisi sampah didapatkan dari perkalian prosentase komposisi sampah pasar dengan timbulan sampah pasar total yang dihasilkan Kota Surabaya. Sehingga diketahui seberapa besar komposisi timbulan sampah pasar yang memungkinkan untuk dilakukan daur ulang. Sampah pasar Kota Surabaya menghasilkan timbulan sampah sayuran dan makanan sebesar 385,87 ton/hari. Komposisi timbulan sampah pasar terbesar kedua yang memungkinkan untuk dilakukan daur ulang adalah timbulan sampah plastik sebesar 19,44 ton/hari. Selain itu, sampah pasar juga menghasilkan sampah kertas, kaca dan logam yang berpotensi dilakukan daur ulang (Tabel 2).

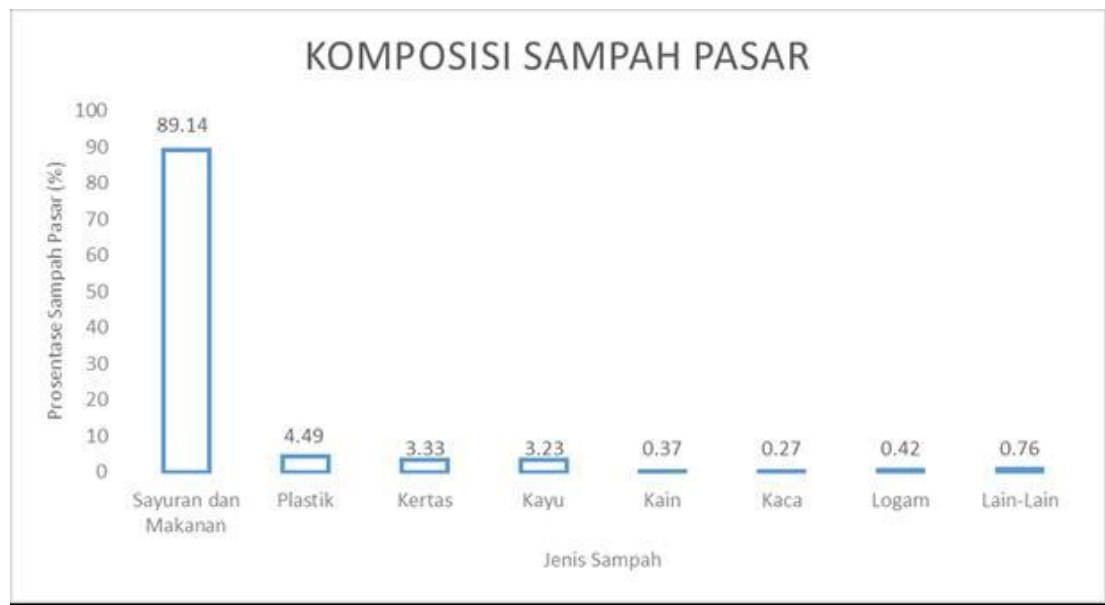

Gambar 2. Prosentase komposisi sampah pasar

Sumber: (Fathoni dan Soedjono, 2011)

Tabel 2. Timbulan sampah pasar berdasarkan jenis sampah

\begin{tabular}{lrlr}
\hline Jenis Sampah & $\begin{array}{r}\text { Timbulan Sampah } \\
\text { (ton/hari) }\end{array}$ & Jenis Sampah & $\begin{array}{r}\text { Timbulan Sampah } \\
\text { (ton/hari) }\end{array}$ \\
\hline Sayuran dan Makanan & 403 & Kain & 1,7 \\
Plastik & 20 & Kaca & 1,2 \\
Kertas & 15 & Logam & 1,9 \\
Kayu & 14,6 & Lain-Lain & 3,4 \\
\hline
\end{tabular}

Sumber: Hasil Perhitungan 


\section{Perhitungan Emisi}

Pada perkiraan perhitungan emisi yang dihasilkan sampah pasar dilakukan 3 skenario. Skenario pertama seluruh sampah pasar dikirim ke tempat pemrosesan akhir (TPA). Skenario kedua adalah dilakukan reduksi terhadap sampah pasar yang mana sampah sayuran dan makanan dilakukan pengomposan, sedangkan sampah kertas, kain, kaca serta logam didaur ulang dan sisanya sampah yang sulit didaur ulang dikirim ke TPA. Skenario ketiga adalah reduksi sampah pasar hanya dilakukan pada sampah sayuran dan makanan melalui pengomposan. Pada masingmasing skenario diperkirakan jumlah gas metana $\left(\mathrm{CH}_{4}\right)$ dan karbondioksida $\left(\mathrm{CO}_{2}\right)$ sebagai emisi gas rumah kaca yang dihasilkan pada kegiatan dari masing-masing skenario.

Pada skenario 1 yang mana sampah pasar dikirim langsung ke tempat pmbuangan akhir. Skenario 1 itu menunjukkan kondisi emisi yang dihasilkan sampah pasar ketika belum dilayani oleh rumah kompos. Berdarkan hasil perhitungan pada skenario 1, pada sektor sampah pasar menghasilkan emisi gas $\mathrm{CH}_{4}$ sebesar 4,9 $\mathrm{Gg} / \mathrm{tahun}$ dengan catatan bahwa TPA masih belum dilengkapi dengan penangkapan gas $\mathrm{CH}_{4}$. Sedangkan emisi gas $\mathrm{CO}_{2}$ yang dihasilkan pada skenario 1 ini sebesar 226,99 Gg/tahun dengan karbon stok 61,91 Gg/tahun. Penghasil terbesar emisi gas $\mathrm{CH}_{4}$ dari sampah pasar ketika tidak dilakukan daur ulang atau reduksi adalah sampah sayuran dan makanan yang mana sampah sayuran dan makanan menghasilkan emisi gas $\mathrm{CH}_{4}$ sebesar 4,1 $\mathrm{Gg} / \mathrm{tahun}$. Selain itu jenis sampah sayuran dan makanan yang dibuang ke TPA menghasilkan gas $\mathrm{CO}_{2}$ sebesar 210,47 $\mathrm{Gg} /$ tahun. Sampah kayu dan kertas menghasilkan emisi gas $\mathrm{CH}_{4}$ terbesar kedua sebesar $0,4 \mathrm{Gg} / \mathrm{tahun}$. Sedangkan emisi gas karbondioksida terbesar kedua dihasilkan oleh sampah kertas sebesar 20,36 Gg/tahun. Berikut pada tabel 3 hasil perhitungan emisi gas $\mathrm{CH}_{4}$ dan hasil perhitungan gas $\mathrm{CO}_{2}$ sampah pasar untuk masing-masing komposisi sampah pasar.

Tabel 3. Emisi gas rumah kaca pada skenario 1

\begin{tabular}{lrrrr}
\hline Jenis Sampah & $\begin{array}{l}\text { Timbulan } \\
\text { Sampah } \\
\text { (ton } \\
\text { /tahun) }\end{array}$ & $\begin{array}{r}\text { Emisi Karbon } \\
\mathbf{( G g / t a h u n )}\end{array}$ & $\begin{array}{r}\text { Emisi CO } \\
\mathbf{( G g / t a h u n )}\end{array}$ & $\begin{array}{r}\text { Emisi Metana } \\
\mathbf{( G g / t a h u n )}\end{array}$ \\
\hline Sayuran dan Makanan & 147.180 & 57,4 & 210,47 & 4,08 \\
Plastik & 7.413 & 0,074 & 0,272 & 0,00 \\
Kertas & 5.498 & 5,56 & 20,36 & 0,41 \\
Kayu & 5.333 & 0,107 & 0,391 & 0,42 \\
Kain & 611 & 0,098 & 0,358 & 0,03 \\
Kaca & 446 & 0,004 & 0,016 & 0 \\
Logam & 693 & 0,992 & 3,64 & 0 \\
Lain-Lain & 1.255 & 0,464 & 1,70 & 0 \\
\hline
\end{tabular}

Sumber: Hasil Perhitungan

Pada Tabel 3 menunjukan komposisi timbulan sampah pasar yang menghasilkan gas $\mathrm{CH}_{4}$ adalah sampah sayuran dan makanan, sampah kertas serta sampah kayu. $\mathrm{Gas}_{\mathrm{CH}} \mathrm{CH}_{4}$ yang terlepas ke udara dihasilkan dari proses degradasi yang terjadi di TPA. Pada perhitungan ini diasumsikan TPA tidak melakukan penangkapan gas $\mathrm{CH}_{4}$. Sedangkan perhitungan emisi gas $\mathrm{CO}_{2}$ didapatkan dari karbon stok yang dihasilkan dari masing - masing sampah. Pada Tabel 3 juga menunjukan masing-masing komposisi sampah pasar melepaskan emisi gas karbondioksida ketika tidak dilakukan daur ulang.

Pada skenario 2 dilakukan reduksi terhadap sampah pasar. Skenario kedua ini didasarkan pada kondisi dilapangan yang mana sampah pasar dipilah dan dikomposkan di rumah kompos. Beberapa rumah kompos sudah dilengkapi sistem daur ulang terhadap sampah plastik, kertas, kaca dan logam. Emisi gas rumah kaca yang dihasilkan pada skenario ini lebih kecil bila dibandingkan dengan emisi gas rumah kaca yang dihasilkan dari sampah yang tidak dilakukan daur ulang atau reduksi. Pada skenario 2 dapat diketahui emisi gas $\mathrm{CH}_{4}$ sebesar 1,83 $\mathrm{Gg} / \mathrm{tahun}$ dihasilkan dari proses pengomposan timbulan sampah sayuran dan makanan, kayu dan kain. Sampah kayu menambah emisi sebesar $0,4 \mathrm{Gg} /$ tahun dan sampah kain menghasilkan emisi sebesar 0,03 $\mathrm{Gg} / \mathrm{tahun}$. Sampah kayu dan sampah kain ini menambah gas $\mathrm{CH}_{4}$ dikarenakan tidak dilakukan daur ulang dan dikirim ke TPA. Emi- 
si karbon yang dihasilkan dari sampah sayuran dan makanan sebesar -26,98 Gg/tahun. Menurut Hapsari dan Wilujeng, (2011) nilai negatif hasil perhitungan emisi karbon dari sampah menunjukan bahwa emisi gas $\mathrm{CO}_{2}$ tersimpan atau tidak terlepas ke udara sehingga dapat dikatakan bahwa pengomposan sampah sayuran dan makanan dapat menyumbang pengurangan emisi karbon sebesar $26,98 \mathrm{Gg} / \mathrm{tahun}$. Hasil perhitungan emisi gas $\mathrm{CH}_{4}$ dan $\mathrm{CO}_{2}$ seluruh komposisi sampah pasar dapat dilihat pada dapat dilihat pada Tabel 4.

Tabel 4. Emisi gas rumah kaca pada skenario 2

\begin{tabular}{lrrrr}
\hline Jenis Sampah & $\begin{array}{r}\text { Timbulan Sampah } \\
\text { (ton /tahun) }\end{array}$ & $\begin{array}{r}\text { Emisi Karbon } \\
\text { (Gg/tahun) }\end{array}$ & Emisi CO $\mathbf{~ ( G g / t a h u n ) ~}$ & $\begin{array}{r}\text { Emisi CH }_{4} \\
(\mathbf{G g} / \text { tahun) }\end{array}$ \\
\hline Sayuran dan & 147.180 & $-7,36$ & $-26,98$ & 1,5 \\
makanan & 7.414 & $-3,11$ & $-11,42$ & 0 \\
Plastik & 5.498 & $-4,29$ & $-15,73$ & 0 \\
Kertas & 5.333 & 0,107 & 0,391 & 0,4 \\
Kayu & 611 & 0,098 & 0,358 & 0,03 \\
Kain & 446 & $-0,036$ & $-0,131$ & 0 \\
Kaca & 694 & 0,992 & 3,64 & 0 \\
Logam & $1.254,8$ & 0,464 & 1,70 & 0 \\
Lain-Lain & & &
\end{tabular}

Sumber: Hasil Perhitungan

Sampah kayu, sampah kain dan lain-lain masing-masing masih melepas emisi gas karbondioksida sebesar 0,391 $\mathrm{Gg} /$ tahun, $0,358 \mathrm{Gg} / \operatorname{tahun}$ dan 1,702 Gg/tahun.ddikarenakan rumah kompos masih belum dapat melakukan daur ulang terhadap kedua jenis sampah tersebut. Sedangkan sampah logam masih melepas emisi karbondioksida sebesar 3,64 Gg/tahun meskipun sudah dilakukan daur ulang.

Pada skenario 3 dilakukan daur ulang atau reduksi hanya pada sampah sayuran dan makanan, sedangkan komposisi sampah selain sampah sayuran dan makanan dikirim ke TPA tanpa dilakukan reduksi. Skenario ketiga ini mewakili suatu kondisi dimana rumah kompos hanya mampu melakukan reduksi dengan pengomposan tanpa upaya reduksi terhadap komposisi sampah yang lainnya seperti sampah kertas, plastik maupun logam. Emisi gas $\mathrm{CH}_{4}$ yang dilepas ke udara pada skenario ketiga sebesar $2,3 \mathrm{Gg} /$ tahun yang berasal dari pengomposan sampah sayuran dan makanan, sampah kertas, sampah kayu dan sampah kain yang dikirim ke TPA. Sedangkan emisi gas karbondioksida yang dihasilkan pada skenario 3 sebesar $-0,245 \mathrm{Gg} /$ tahun. Sehingga dengan adanya reduksi sampah sayuran dan makanan akan mampu mengurangi emisi gas $\mathrm{CH}_{4}$ dan mampu menyimpan emisi atau mengurangi emisi karbondioksida sebesar $0,245 \mathrm{Gg} /$ tahun.

Tabel 5. Emisi gas rumah kaca pada skenario 3

\begin{tabular}{|c|c|c|c|c|}
\hline Jenis Sampah & $\begin{array}{r}\text { Timbulan Sam- } \\
\text { pah (ton } \\
/ \text { tahun) }\end{array}$ & $\begin{array}{r}\text { Emisi Karbon } \\
\text { (Gg/tahun) }\end{array}$ & Emisi $\mathrm{CO}_{2}(\mathrm{Gg} /$ tahun $)$ & Emisi $\mathrm{CH}_{4}(\mathrm{Gg} /$ tahun) \\
\hline $\begin{array}{l}\text { Sayuran dan } \\
\text { makanan }\end{array}$ & 147.180 & $-7,36$ & $-26,98$ & 1,5 \\
\hline Plastik & 7.413 & 0,074 & 0,272 & 0 \\
\hline Kertas & 5.498 & 5,55 & 20,36 & 0,39 \\
\hline Kayu & 5.333 & 0,107 & 0,391 & 0,41 \\
\hline Kain & 611 & 0,098 & 0,358 & 0,03 \\
\hline Kaca & 446 & 0,004 & 0,016 & 0 \\
\hline Logam & 693 & 0,992 & 3,64 & 0 \\
\hline Lain-Lain & 1.255 & 0,464 & 1,70 & 0 \\
\hline
\end{tabular}

Sumber: Hasil Perhitungan

\section{Perbandingan Emisi Setiap Skenario}

Emisi tertinggi gas rumah kaca yang terlepas di udara dihasilkan oleh skenario 1 yang mana pada skenario 1 ini tidak dilakukan reduksi maupun daur ulang serta langsung dikirim ke TPA. Emisi gas $\mathrm{CH}_{4}$ yang dihasilkan oleh 
skebario 1 sebesar 4,9 Gg/tahun, skenario 2 sebesar 1,5 (Gg/tahun) dan skenario 3 sebesar 2,3 Gg/tahun (Tabel 6). Adanya reduksi dan daur ulang sampah yang dihasilkan sektor pasar dapat mengurangi emisi gas $\mathrm{CH}_{4}$ sebesar $3,4 \mathrm{Gg} /$ tahun dan adanya reduksi sampah sayuran dan makanan dari sektor pasar dengan pengomposan dapat mengurangi emisi gas $\mathrm{CH}_{4}$ sebesar $2,5 \mathrm{Gg}$ /tahun. Reduksi sampah pasar dengan mengomposkan sampah sayuran dan makanan dapat mengurangi sekitar $53 \%$ emisi gas $\mathrm{CH}_{4}$ yang dihasilkan oleh sampah pasar. Hal ini disebabkan sampah sayuran dan makanan dari sektor pasar di Surabaya merupakan jenis sampah yang mendominasi komposisi sampah pasar di Kota Surabaya. Adanya pengomposan sampah sayuran dan makanan merupakan langkah yang sangat baik dalam melakukan reduksi emisi gas $\mathrm{CH}_{4}$ yang terlepas di udara.

Tabel 6. Perbandingan emisi setiap skenario

\begin{tabular}{ccc}
\hline $\begin{array}{c}\text { Jenis Gas } \\
\text { Rumah Kaca }\end{array}$ & $\begin{array}{c}\mathbf{C H}_{4} \\
\text { (Gg/tahun) }\end{array}$ & $\mathbf{C O}_{\mathbf{2}}$ (Gg/tahun) \\
\hline Skenario 1 & 4,9 & 237,21 \\
Skenario 2 & 1,5 & $-48,17$ \\
Skenario 3 & 2,3 & $-0,245$ \\
\hline
\end{tabular}

Sumber: Hasil Perhitungan

Pada tabel 6 menunjukkan bahwa emisi gas $\mathrm{CO}_{2}$ tertinggi dihasilkan oleh skenario 1 . Sedangkan skenario 2 mampu mengurangi atau menahan emisi gas $\mathrm{CO}_{2}$ ke udara sebesar 48,17 Gg/tahun. Skenario 3 mampu menurangi emisi sebesar $0,245 \mathrm{Gg} /$ tahun. Hal ini menunjukkan adanya daur ulang sangat berpengaruh terhadap reduksi emisi gas $\mathrm{CO}_{2}$. Sebagian besar komposisi sampah pasar adalah sampah sayuran dan makanan sehingga adanya reduksi dengan pengomposan pada scenario 2 dan scenario 3 akan memberian dampak penurunan stok karbon, emisi $\mathrm{CH}_{4}$ dan $\mathrm{CO}_{2}$ yang cukup signifikan. Ketika adanya reduksi terhadap sampah selain sayuran dan makan juga memberikan dampak penurunan emisi GRK kecuali reduksi atau daur ulang terhadap sampah logam. Meskipun adanya daur ulang sampah logam tidak menurunkan emisi GRK, komposisi logam pada sampah pasar tidak cukup besar sehingga emisi yang ditimbulkan juga tidak begitu besar. Oleh karena itu dengan adanya reduksi atau daur ulang pada sumber sampah pasar akan mampu menurunkan stok karbon, emisi $\mathrm{CH}_{4}$ dan $\mathrm{CO}_{2}$. Akan tetapi menurut Addiansyah dan Herumurti, (2017) jika dalam proses daur ulang terdapat proses pembakaran dan penggunaan bahan bakar fosil maka proses tersebut dapat meningkatkan emisi GRK. Sehingga perhitungan emisi dari skenario 2 dan skenario 3 akan sesuai jika dalam proses daur ulang aatau reduksi tidak terdapat proses pembakaran dan proses daur ulang menggunakan alat yang ramah lingkungan.

\section{SIMPULAN}

Emisi terbesar gas $\mathrm{CH}_{4}$ dihasilkan oleh skenario 1 sebesar 4,9 $\mathrm{Gg}$ /tahun, sedangkan emisi $\mathrm{CO}_{2}$ terbesar dihasilkan oleh gas skenario 1 sebesar 237,21 Gg/tahun. Adanya daur ulang sampah kertas, plastik, logam, kaca, sayuran dan makanan akan mengurangi emisi $\mathrm{CH}_{4}$ yang signifikan dari 4,9 $\mathrm{Gg} /$ tahun menjadi $1,5 \mathrm{Gg} /$ tahun dan mengurangi emisi $\mathrm{CO}_{2}$ dari $237,21 \mathrm{Gg} /$ tahun menjadi $-48,17 \mathrm{Gg} /$ tahun. Daur ulang sampah sayuran dan makanan pada skenario 3 mampu mengurangi emisi $\mathrm{CH}_{4}$ yang cukup besar sehingga emisi $\mathrm{CH}_{4}$ menjadi 2,3 $\mathrm{Gg} /$ tahun dan emisi $\mathrm{CO}_{2}$ menjadi $-0,245 \mathrm{Gg}$ /tahun. Pegurangan emisi GRK ini akan signifikan jika tidak ada proses pembakaran dan tidak ada penggunaan alat daur ulang yang menggunakan bahan bakar fosil.

\section{REKOMENDASI}

Perlu adanya penelitian lanjutan terkait emisi gas rumah kaca dari timbulan sampah pasar dengan memperhatikan proses pengangkutan timbulan sampah pasar menuju rumah kompos maupun menuju tempat pemrosesan akhir dan emisi yang dihasilkan dari alat yang digunakan untuk daur ulang.

\section{UCAPAN TERIMAKASIH}

Ucapan terimakasih kepada seluruh pihak yang membantu penelitian ini.

\section{REFERENSI}

Addiansyah, A., \& Herumurti, W., 2017, "Studi Timbulan dan Reduksi Sampah Rumah Kompos serta Perhitungan Emisi Gas Rumah Kaca di Surabaya Timur", Jurnal Teknik ITS. Vol. 6, 62-67.

Andina, E., 2019, "Analisis Perilaku Pemilahan Sampah di Kota Surabaya”, Jurnal Masalah-Masalah Sosial. Volume 10, No. 2 Desember 2019. 
Anonim, 2008, “Undang-Undang Republik Indonesia Nomor 18/2008 tentang Pengelolaan Sampah", https://peraturan.bpk.go.id/Home/Details/39067/uu-no-18-tahun-2008. diakses 30-9-2020.

Dinas Lingkungan Hidup Pemerintah Kota Surabaya., 2014, "Laporan Status Lingkungan Hidup Kota Surabaya", http://lh.surabaya.go.id/fileupload/ebook/BUKU\%20LAPORAN\%20SLHD\%202014.pdf. diakses 30-9-2020.

Fathoni, A.K.R. dan Soedjono, E.S., 2011, "Perencanaan Tipikal Rumah Kompos untuk Pengolahan Sampah Pasar Tradisional (Studi Kasus di Kota Surabaya)", http://digilib.its.ac.id/public/ITS-Undergraduate15976-3307100090-paperpdf.pdf. diakses 30-9-2020.

Hapsari, C. dan Wilujeng, S.A., 2011, "Studi Emisi Karbon Dioksida $\left(\mathrm{CO}_{2}\right)$ dan Metana $\left(\mathrm{CH}_{4}\right)$ dari Kegiatan Reduksi Sampah di Wilayah Surabaya Bagian Selatan", Tugas Akhir. Jurusan Teknik Lingkungan Fakultas Teknik Sipil dan Perencanaan Institut Teknologi Sepuluh November, Surabaya.

Intergovernmental Panel on Climate Change (IPCC), 2006, "WASTE -IPCC Good Practice Guidance and Uncertanty Management in National Greenhouse Gas Inventories", Jenewa: IPCC.

Kementerian Lingkungan Hidup dan Kehutanan., 2020, "Data Umum Sistem Pengelolaan Sampah Nasional", http://sipsn.menlhk.go.id/?q=3adataumum\&field_f_wilayah_tid=1519\&field_kat_kota_tid=All\&field_pe riode_id_tid=2168. diakses 20-12-2020.

United State Environmental Protection Agency (US-EPA) ,2002, “Waste Wise Update”, Washington: US-EPA. 